\title{
THE NEW MODE OF GOVERNANCE IN EUROPEAN EDUCATION - IN THE CONTEXT OF GLOBALIZATION AND EU-IFICATION
}

\author{
HOLGER DAUN
}

Stockholm University

\begin{abstract}
Certain types of educational reforms are discussed or even implemented in many countries around the world. Their features are rather similar, at least in discourse and policy formulation, and it may be assumed that they derive from what could be called the world agenda or world models in education. The core of these models may be extracted from the documents published by the large international organizations (OECD, UNESCO, the World Bank). In the case of Europe, the European Union (EU) has added a dimension to this world agenda, and the EU agenda is disseminated through the Open Method of Coordination (OMC), among other measures and channels. This paper compares educational changes in three European countries in the light of the European and the world agendas.
\end{abstract}

Key words: educational reforms, comparative perspective, EU, OMC, globalization, educational governance

\section{Introduction}

In Europe, educational policies were to a large extent conditioned by factors internal to each country until the end of the 1980s. Since then, changes in educational governance ${ }^{1}$ need to be seen in the context of globalization and Europeanization. This paper makes a short review of World systems perspectives, globalization and Europeanization and then an overview of changes in educational governance in Europe. Three European countries with different characteristics (Czech Republic, Greece and Sweden) are compared along selected dimensions of educational governance. These countries have been selected so as to illustrate different backgrounds and developments and differences in the degree of implementation of the standardized policies deriving from borrowing from world models and single countries. The description, based on documents presented by EU and OECD and on various research works. The paper focuses on formulated and

1 We make the following distinction: Governing is what governments traditionally have used, while governance is substantially broader and includes different (vertical as well as horizontal) forces steering processes and outcomes (see Gornitzka, 2006, p. 11). 
"officialized" policies (Apple, 1991) in primary and lower secondary education.

In many respects Europe differs from other continents in that modernization was accompanied by secularization and a declining importance of traditional religious values in large parts of the continent (Berger, 1999; Davie, 1999; Norris \& Inglehart, 2004). However, Europe has maintained a Christian foundation in its educational systems. On the other hand, the European elites increasingly demand education principally as formation of competitive human capital (European Commission, 2004; Karlsen, 2002; Steenbergen et al., 2005; Sultana, 1995). Also, there are substantial economic, political, religious and cultural differences, relevant in relation to education and its governance, among the countries, in: economic level; degree of cultural homogeneity-heterogeneity; religious pattern; type of state; and type of response to and interaction with Europeanization and global processes. This is despite trends of convergence due to globalization and EU interventions.

\section{European Characteristics}

The states differ in ways that have bearings on education, such as degree and type of corporatism, immigration, and response to and interaction with globalization processes. (Cerny, 2003; Gilbert, 2004). For example, there are different models of capitalism (Radaelli, 2003). Among the fifteen countries ${ }^{2}$ that were members of the EU in the beginning of the 1990s, the GDP per capita varied in 2005 from 19,954 US dollars in Greece to 37,738 in Ireland, and the variation became still larger when the east and south European countries became members. The gap between the "richest" and the "poorest" among the fifteen countries increased in absolute terms between 1990 and 2005 (UNDP, 2005). Due to economic and technological levels as well as cultural differences, the way of organizing production and work varies a lot across European nations. In addition, there are, within each country rather large socio-economic and geographical inequalities, mainly in Greece, Spain, Lithuania, Cyprus, and Ireland (Otero \& McCoshan, 2004).

Traditionally, degree of state corporatism has been a factor likely to condition educational policies. Corporatism is a more or less permanent cooperation between different interests and the state. If we include only labour market parties and material interests, Austria, the Netherlands, Norway and Sweden traditionally have had a high degree of corporatism, while France, Spain, and the UK have had a low degree (Johnson, 1987; O'Connel, 1989). (For historical reasons, CR has not been included in studies dealing with corporatism) ${ }^{3}$.

With liberalization of the economies and increasing globalization, these internal corporatist relationships have been partially undermined and partially replaced by neo-corporatism and intensifying connections between single states and international government organizations (IGOs), such as EU, OECD, etc.) and non-

2 "Nation" and "country" are used interchangeably here. "State" refers to the central, authoritative steering body and its executive branches in a country,

3 Czech Republic, Greece and Italy have not been included in the studies of corporatism known to the author. 
governmental organizations (NGOs) (Cerny, 2003).

When it comes to religious interests, the private sector of the education systems has traditionally been conditioned by religious patterns as well as church-state relationships. In Protestant countries (e.g. Denmark, England, Finland, Iceland, Norway, and Sweden), where religion became the state religion, religious interests and the church have, during the past decades, to a large extent been marginalized from educational matters, and the private sector has been comparatively small (with the exception of Denmark). In a second group of countries (mainly southern European countries), the church is separate from the state but has been able to exert influence over educational policies through corporatist arrangements (negotiations, tacit agreements, etc.). In a third group of countries (some of the former communist countries), the churches have generally not had any power over educational matters. However, Poland and to some extent in Hungary are exceptions (Greger \& Walterová, 2007; Halász, 2007; Janowski, 2007; Kozma, 1992; Offe, 1996).

People in Austria, Ireland, Italy, and Spain are the most religious (Christian), while the populations of the Nordic countries, England, France, and the Netherlands are the most secular as measured along the dimensions used in the World Values Study (Norris \& Inglehart, 2004). Ethnical or religious minorities exist traditionally in several European countries (e.g. Czech Republic, and Greece).

During the past three decades, immigration has added to the traditional diversity. Despite EU efforts (through the Open Method of Coordination - OMC, for example), the European countries still are very different in this regard. In some countries immigration is of long duration and they have ended up with a large proportion of individuals of "foreign" background, while another group of countries (e.g. Sweden) started rather recently to receive a large number of immigrants. A third group (e.g. Czech Republic and Greece) has continued with restrictive immigration policies. Due to this variation, the percentage of students with immigrant backgrounds differs (from less than one per cent in $\mathrm{CR}$ and Greece, for example to more than ten per cent in Sweden to15 or more per cent in Belgium and Germany) (European Commission, 2004).

Finally, the elites in Europe tend more than the population in general to be internationally oriented and global and pro-European in their world view and to prioritize education producing cultural and human capital (Andeweg, 1996; Norris \& Inglehardt, 2004; Steenbergen et al., 2005). 


\section{World System (WS) and Globalisation}

In the 1970s, globalization started to accelerate. Two different types of theories are relevant here: world systems theory (WS) and globalization theories. According to the politico-economic WS approach (Dale, 2000; Elwell, 2006; Wallerstein, 2006) states act so as to improve the conditions for competitiveness and profit-making, while the neo-institutionalists (Meyer et al., 1997) suggests that there is a world polity (more or less a symbolic and discursive entity) in addition to national policies. National decision-makers act so as to make their countries more modern or appear as more modern and in this way improve their position in the international/global arena. For the European countries there is an explicit EU goal to make the union the world's most competitive knowledge economy (Gornitzka, 2006). We need to apply a combination of elements from both types of WS theories; education is restructured according to the requirements and demands of the economy (to make people and countries competitive) (Dale, 2000), and the world polity (embodying world models) informs governments about "appropriateness" of different elements in education systems and types of educational governance. National governments are encouraged, persuaded, and so on, to borrow elements or packages from the world models (Meyer et al., 1997). For example, a review of policy documents published by the big international governmental organizations shows that decentralization, privatization and choice are important elements in these models (Daun, 2006).

The views differ as to what globalization is: (a) a processes of compression of the world (in space and time) through ICT; (b) the processes of extending interactions and interdependencies of various types (Cox, 2000; Gill, 2000) (in particular economic interdependencies of global reach); (c) an ideology (Cox, 2000), or "the intensification of consciousness of the world as a whole" (Robertson, 1992, p. 8), but also (d) the spread around the world of educational models and ideas; for example, how to govern and steer educational processes. What comes out of these global influences is filtered and localized by the internal characteristics of each national society (economic level, organization of production, cultural-religious pattern, and so on).

Economically, the EU has been a facilitator of globalization; it is to a large extent doing within its territory what globalization does worldwide (spread of neo-liberal ideas and policies) (Apeldorn, 2000), as well as a filter by requiring its members to introduce customs and tariffs in relation to goods and services coming from outside the union. In the discourse, however, EU also makes efforts to maintain a social dimension. Fractions of the EU decision-makers and administrators have the ambitions is to counter balance and complement the market forces with a social profile (to "internationalize Keynesianism") (Apeldorn, 2000; Cerny, 2003; Otero \& McCoshan, 2004). This discourse includes concepts such as third way between competitiveness/market and cohesion/social inclusion; between inter-governmentalism and suprationalism; between neo-liberalism and social democracy; and the concept of "hybrid" welfare state (Gornitzka, 2006; Radaelli, 2003; Tucker, 2003). 


\section{Europeanization, EU and the Open Method of Coordination (OMC)}

Education has always been seen as a national affair, and national educational diversity among the European countries as legitimate; the education systems have been closely related to the nation-states, nation-building and citizenship. The member countries have not been willing to transfer legal competencies to the European level (Gornitzka, 2006). Education was an area where the question was not "can policies be coordinated - but "should they be" (ibid., p. 48). Generally sensitive issues such as social welfare and education had been avoided at the European level.

However, in 2000, the aim of the European Council meeting in Lisbon, was to make Europe "the most competitive economy (later the most competitive knowledge economy) in the world (Gornitzka, 2006; Radaelli, 2003), and education was seen as one of the principal instruments in this struggle. The Open Method of Coordination $(\mathrm{OMC})$ was launched as a way to modernize and improve different sectors (including education) of the European societies. From the beginning of the new millenium "the question was apparently no longer whether it was a good idea to coordinate Member States' education policy, but how this could be made possible" (Gornitzka, 2006, p. 13). The OMCs were a means to steer the member countries in a "soft" way towards the over-riding goal; education systems were to respond to the requirements of the knowledge economy. However, the Lisbon summit opened up for the launching of "a method that in principle could enable a common European approach also in education" (ibid., p. 12). Later the following goals were then established for education: (a) improved quality and effectiveness of education, (b) improved access to education and (c) opening up national education and training systems to society. These goals were to be achieved in 2010 through a 10 year work programme.

Coordination and mutual learning were to take place through demonstration of best practices (later good practices), performance indicators and benchmarks for monitoring (Radaelli, 2003; Tucker, 2003). Quantifiable targets were established and comparable standardized indicators defined. In OMC education, the benchmarks are seen as "reference points for where the EU would like to be in 2010" (Gornitzka, 2006 , p. 36). According to Gornitzka (2006, p. 3), "The main elements of the OMC (are) ... 1) identifying and defining common goals for the Union with specific timetables for achieving them; 2) establishing indicators and benchmarks for assessing progress towards the goals; 3 ) translating common objectives to national and regional policies taking into account national and regional differences; and 4) engaging in periodic monitoring, evaluation and peer review organised as mutual learning processes". Mutual learning is the basic feature of the OMC governance. There are different thematic working groups (clusters and peer review groups) under the Commission, working group for indicators and benchmark have been established. 
Some principal outcomes or results of the "general" OMCs have according to Gornitzka (2006), Radaelli (2003), and Tucker (2003), been: competitiveness is a 'master discourse'(Radaelli, 2003, p. 20) legitimizing concerted efforts among the EU members; OMC varies considerably across policy areas. In its ideal typical form, $\mathrm{OMC}$ is a new form of governance. OMCs have created a normative framework, and with this type of governance, governmental and societal actors may be "pressured to either adhere to the prescriptions (OMC guidelines) or provide evidence-based arguments to defend their interests and actions within the normative and cognitive framework being produced by the Lisbon OMCs" (Tucker, 2003).

In the comparisons taking place (at least implicitly through the usage of indicators), "a normative pressure is placed on countries to look good and fear embarrassment" (Gortnitzka, 2006, p. 46). The norms developed within the OMC framework have reached a taken-for-granted status, and the Lisbon "is an ideology that persuades, argues, and stigmatizes..." (Tucker, 2003), and the "EU has incrementally built a supranational administration specifically for education as a policy area .. This level relies heavily on the networks that tie together levels of governance and actors in European education" (Gornitzka, 2006, p. 25). Also, it is likely that the tools used and the monitoring and reporting make the mind sets of national policy-makers directed towards the European implict or explicit requirements.

The OMCs have by some researchers and policy-makers been named The New Mode of Governance (Radaelli, 2003). However, as we shall see, this is a rather narrow conceptualization of the New Mode of Governance because it excludes a number of forces that condition educational processes and their outcomes.

\section{The New Mode of Governance}

Traditionally states have been governing education through: regulation/ control; economic measures, and ideological measures. In the educational domain, regulation and ideological measures have traditionally been the most common means (for example, definition and selection of knowledge to be handled in schools through the curriculum, syllabi, teacher guidelines, etc.). In practice, these modes of intervention overlap or combine. Globalization (including the dissemination of neo-liberalism) is changing the conditions for the traditional modes of state governing and intervention by restructuring national societies and education. With the comprehensive changes in education (e.g. networks, decentralization and introduction or reinforcement of market mechanisms in the public sector) during the past decades, the state leaves - either deliberately or as adaptation to globalization forces - to the market and civil forces to implement and administer educational issues. Europeanization is taking place through the OMCs and otherwise, but in each country the central level establishes the parameters of decision-making and actions for bodies at lower levels. The state employs "productivity criteria" (subsidy per pupil) and ideological measures, such as scienticization, information, persuasion and self-regulation, efforts to influence 
the public discourse and mind sets and retroactive monitoring by the help of evaluations, testing of student achievement and commissioned research. With deregulation and decentralization, "horizontal" forces contribute more than before to the shape and content of educational processes and their outcomes.

What has been described so far may be termed the New Mode of Governance (NG) which works vertically between different levels of decision-making power and administration (from the national level to school level) as well as horizontally between, on the one hand, education and schools, and on the other hand, social systems and forces at the same level (Kooiman, 2000). One important feature of the NG is that it to a large extent allows forces other than monitoring and accountability requirements to steer educational processes For example, the policies of restructuring (decentralization, privatization and choice) are initially driven from the political arena but with the transfer of their implementation and funding to levels below the national level, other steering forces start to work. Therefore, it is necessary to use a broader concept of educational governance, including change of mentalities (Foucault, 1991; Gordon, 1991). OMC, then, is but one component or aspect in this wider definition of NG.

The components of the NG may be divided into steering mechanisms (which are deliberate mechanisms or instruments) and steering forces (Hamilton, 2003; Hannaway \& Woodroffe, 2003). At the local level, they are condensed and combine with everyday practice. Deliberate steering and monitoring mechanisms include: national curriculum or national goals and guidelines; local arrangements for "site involvement" ", participation and decision-making; inspection or monitoring of attainment of national goals from the central level; accountability requirements (including testing, reporting of student achievement, economic accounts, etc. from lower to parallel or higher levels or to boards/councils at the local level), selfevaluation/self-assessment; market mechanisms (per pupil pay to schools, choice possibilities, vouchers, etc.); and privatization. All these allow market and civil society actors to contribute to the educational processes and their outcomes.

Steering forces include the scope of a decentralization program (general for all sectors or specific to education); constitutional status of decentralization (from simple delegation or de-concentration to devolution protected in the Constitution); socio-economic and cultural context (economic level, political culture, cultural heterogeneity-homogeneity, etc.); ideological orientations in society and stimulation of self-regulation (Daun, 2006). The cultural and economic contexts as well as existing choice-opportunities, the formulas for allocation of resources and the catchment area of the school vary (see e.g. Abu-Duhou, 1999; Ladd, 2003; Welsh \& McGuinn, 1999). 


\section{Educational Governance in Europe}

The mode of governing in the education systems in Europe differed prior to accelerated globalization, so the change of governance started from very different baselines (Daun, 2002; Daun 2008). This change is sometimes and in some countries in the direction of the NG and will here be described along certain strategic dimensions, such as: size of the private sector in education; degree of decentralization - centralization; degree and type of regulation, control and monitoring; types and levels of subsidies to private schools; and choice possibilities.

The size of the private sector in education varies according to the extent to which private schools are: allowed to give compulsory education even if they are not approved; are subsidized; controlled/regulated, inspected; compelled to teach a centrally established curriculum; and are teaching religion is a part of the curriculum (Daun, 2008). How these variables combine is conditioned by national features in interaction with globalization and Europeanization processes. Relevant are also internal interactions - between religious pattern, degree of corporatism, role of the church, on the one hand, and private education on the other.

The size of the private sector has traditionally been comparatively large in Catholic and culturally heterogeneous countries. In Europe, the proportion of pupils enrolled in private schools varies from 100 per cent in Ireland and 70 per cent in the Netherlands to one to two per cent in Finland and Norway (Unesco, 2005). Private school enrolment is largest and the range of variation in this enrolment is widest in among Catholic countries, even if the extreme case of Ireland is excluded. With the changes since the beginning of the 1990s, this sector has grown in Sweden only; the percentage of comprehensive school students in private schools increased from less than one cent in the beginning of the 1990s to more than six in 2009 (Skolverket, 2010).

All countries regulate how schooling should be organized and the content of compulsory education (Eurybase, 2005). Non-approved private schools (without state subsidies) are legitimate alternatives for compulsory education in some countries but not in the three case countries.

Where regulation and control was very strict until the 1990s, it has been relaxed (e.g. CR and Sweden) (Greger \& Waltarová, 2007). Although they tend to apply stricter rules than before 1990, some Catholic countries continue to accept nonapproved schools to organize compulsory education. Pro-active regulation has been relaxed in several countries (e.g. CR and Sweden) and has to some extent been replaced by evaluation, testing and accountability mechanisms. Accountability emerged as a theme in the 1990s and mostly implies self-evaluation reports and school reports to stakeholders at the local level and to higher level authorities, reporting on student achievement, budget, and so on.

Countries with large subsidies and having different types of contract between the state and the school also tend to have a comparative large proportion of students in private schools. Subsidies to private schools vary from zero to 100 per cent of the cost of a student in the public sector in Catholic countries (Eurydice, 2006). 
Protestant countries have the highest minimum level of subsidy to private schools, which seems to indicate that they are likely to provide funding if they have approved the schools. From the beginning of the 1990s, practically all EU countries (except Greece) allocate subsidies to private schools. In some countries (e.g. Netherlands and Sweden) only not-for-profit schools are subsidized (Eurydice, 2006). Also, in most countries (including the three case countries), there is a centrally established framework for the content and it has to be taught also in private schools, if they are approved. National testing has for a long time been very systematic and strict in France and Sweden, and is now being introduced in more and more countries.

Practically, market mechanisms did not exist in any country before mid-1980s. Such mechanisms have then been introduced in several countries and among the three case countries they are of importance in CR and Sweden. The latter country has the most radical arrangement, more radical than in New Zealand and in many states in the US, for example.

With the restructuring of education systems, the units of inspection disappeared or were at least given a less important role in some countries. (e.g. CZE, England and Sweden) but have then been revived and reinforced. Specific bodies for steering, monitoring and assessment have been established where such bodies did not exist before.

\section{Choice}

We may distinguish between two types of choice: value-based choice (based in pedagogical and/or religious considerations) and market choice (based in human capital and academic considerations). Choice possibilities have traditionally existed in several countries, while countries practically without choice arrangements before 1990 (e.g. CZE, Finland, Norway and Sweden) have during the past two decades introduced them but mainly on a market basis.

The Netherlands, France and Spain have by tradition choice arrangements related to choice based on values (religion). The Netherlands has traditionally had wide choice opportunities, which have been exploited by the parents almost exclusively on the basis of religious or pedagogical concerns. Choice linked to market mechanisms has then been introduced in CZE and Sweden, while the situation in Greece has not changed very much in this regard.

However, in countries such as those in southern Europe, market mechanisms have not been implemented or have not been exploited by parents or schools to any large extent (Eurybase, 2005). In other countries (e.g. CZE, Finland, Iceland and Norway) market mechanisms have been introduced during the past two decades but parents have not responded to them to the same extent as in Sweden. In the CZE, schools charge fees and this is evidently the principal reason for parents not to choose private schools to a larger extent than they do. 


\section{Decentralization/centralization}

Before the era of NG, decision-making competence was in most countries (e.g. $C R$, and the Nordic countries, France and Greece) situated the central level, while it was comparatively decentralized in England, Germany and Switzerland (Eurydice, 2007; OECD, 1995). Decision-making has during the past two decades been moved to lower levels, often in combination with the introduction or reinforcement of market mechanisms and freedom of choice have been introduced. CR and Sweden have decentralized radically, France and Netherlands less and Greece and Italy not very much in practice.

Decentralization programs differ considerably between countries in in at least the following regards: baselines from which decentralization starts and the level to which the tasks or decision-making power is moved; type of decentralization; tasks or issues being decentralized, and whether there are mechanisms for participation at the school level or not. We may distinguish between four types of decentralization. Deconcentration is the transfer of work and tasks from higher to lower levels within the administration; decision-making power is not transferred. Most often issues have been moved from national to provincial level (e.g. France, Greece, Italy and Spain). Delegation implies conditional transfer of decision-making power or administrative tasks to lower levels in the hierarchy. Devolution is the transfer of authority to autonomous units or local bodies. This has been the most common type of decentralization in CR and the Nordic countries, for example. Finally, sometimes privatization is seen as a type of decentralization (Welsh \& McGinn, 1999).

In practice, countries often employ a mixed approach. For example, Sweden has devolved most of the decision-making power and issues to the municipality level and some to the school level. Then municipalities in varying degrees have delegated decision-making power and issues to the school level (more precisely: to the school head).

Table 1. Baselines and Levels of Decentralization and Centralization, Some Examples

\begin{tabular}{|l|l|l|l|l|}
\hline From level & To level & & & \\
\hline & $\begin{array}{l}\text { Central/ } \\
\text { national }\end{array}$ & Region/state & $\begin{array}{l}\text { Municipality/ } \\
\text { district }\end{array}$ & School \\
\hline Central -> & - & Greece, & $\begin{array}{l}\text { Czech } \\
\text { Republic, } \\
\text { Sweden }\end{array}$ & Sweden \\
\hline Region/state -> & & & $\begin{array}{l}\text { Czech Republic } \\
\text { Sweden }\end{array}$ & Sweden \\
\hline $\begin{array}{l}\text { Municipality/ } \\
\text { district -> }\end{array}$ & & & - & Sweden \\
\hline School -> & & & & - \\
\hline
\end{tabular}


The issues most commonly being decentralized are: evaluation, recruitment of school principals and teachers, services, school construction, and financial and management audit.

Finally, centralization (or re-centralization) has taken place in some countries and of certain issues. For example, in England curriculum and evaluation have been centralized.

Europeanization has so far influenced, not so much the policies of individual countries' mode of governance in education, but rather the view of what should be the principal role of education in society and what educational quality is, i.e. ideas and mind sets of people. On the benchmarks and indicators, some countries "come up at the top (Finland and Sweden), some at the bottom (Greece and Poland) (Gornitzka, 2006, p. 47). And Radaelli (2003, p. 47) found that southern European countries (e.g. Greece), more than others, were under pressure to adapt to the standards. (Researchers have not yet explored to what extent the OMCs and other measures of Europeanization have affected national education systems. $)^{4}$ It may then be assumed that the world models (spread via OECD, UNESCO and other international governmental organizations) inform national ministries of education about the mode of educational governance required or appropriate in order for this to be achieved.

Some principal characteristics of the three case countries and the components of their educational governance are presented in Table 2.

Table 2. Comparison Between the Seven Case Countries in Some Governance Components

\begin{tabular}{|l|l|l|l|}
\hline & Czech Republic & Greece & Sweden \\
\hline $\begin{array}{l}\text { Religious } \\
\text { pattern }\end{array}$ & Heterogeneous & $\begin{array}{l}\text { Homogeneous. } \\
\text { Orthodox }\end{array}$ & $\begin{array}{l}\text { Homogeneous. } \\
\text { Lutheran }\end{array}$ \\
\hline Type of state & Centralized. & Centralized. & $\begin{array}{l}\text { Centralized. Strong } \\
\text { corp. }\end{array}$ \\
\hline $\begin{array}{l}\text { Globalization } \\
\text { - Europeani- } \\
\text { zation }\end{array}$ & $\begin{array}{l}\text { Medium globalized. } \\
\text { Mixed approach. } \\
\text { Elites divided } \\
\text { in relation to } \\
\text { Europeanization }\end{array}$ & $\begin{array}{l}\text { Weakly globalized. } \\
\text { Closed approach. } \\
\text { Elites not very pro- } \\
\text { European }\end{array}$ & $\begin{array}{l}\text { Strongly globalized. } \\
\text { Open approach. } \\
\text { Elites divided } \\
\text { in relation to } \\
\text { Europeanization. }\end{array}$ \\
\hline $\begin{array}{l}\text { Centr/ } \\
\text { dec }\end{array}$ & $\begin{array}{l}\text { From national level } \\
\text { to districts and } \\
\text { municipallities and } \\
\text { then to province. }\end{array}$ & $\begin{array}{l}\text { From mini-stry } \\
\text { to regions and } \\
\text { municipalilities. }\end{array}$ & $\begin{array}{l}\text { From national level } \\
\text { to municipality and } \\
\text { school levels. School } \\
\text { head. }\end{array}$ \\
\hline
\end{tabular}

4 The author of this paper got some insights into the working and functioning of peer review groups and clusters when he served as a consultant in this context. It seemed that a few country representatives participate frequently in the meetings and took initiative to host meetings, while other country representatives participated sporadically. 


\begin{tabular}{|c|c|c|c|}
\hline $\begin{array}{l}\text { School- } \\
\text { based bodies }\end{array}$ & $\begin{array}{l}\text { School councils } \\
\text { obligatory }\end{array}$ & $\begin{array}{l}\text { PTA and teacher } \\
\text { committee }\end{array}$ & $\begin{array}{l}\text { Municipality board } \\
\text { and school director }\end{array}$ \\
\hline Choice & $\begin{array}{l}\text { From none to } \\
\text { full choice. Open } \\
\text { enrollment }\end{array}$ & $\begin{array}{l}\text { Possible to } \\
\text { upper secondary } \\
\text { but rarely to } \\
\text { compulsory. }\end{array}$ & $\begin{array}{l}\text { From none to } \\
\text { full choice: Open } \\
\text { enrolment. Market } \\
\text { forces. }\end{array}$ \\
\hline $\begin{array}{l}\text { Market } \\
\text { mechanisms }\end{array}$ & $\begin{array}{l}\text { Subsidy per } \\
\text { student, choice, } \\
\text { competition. } \\
\text { In reality very few } \\
\text { parents choose }\end{array}$ & $\begin{array}{l}\text { Theoretical-ly but } \\
\text { in reality very few } \\
\text { parents choose }\end{array}$ & $\begin{array}{l}\text { Subsidy per } \\
\text { student, full choice, } \\
\text { competition }\end{array}$ \\
\hline Private & Stable $<1 \%$ & From $>1$ to $2 \%$ & From 1 to $7 \%$ \\
\hline $\begin{array}{l}\text { Subsi- dies to } \\
\text { private }\end{array}$ & $\begin{array}{l}\text { From none to not- } \\
\text { for-profit schools. } \\
\text { Related to per } \\
\text { student cost in } \\
\text { public schools. }\end{array}$ & None $\left(^{*}\right)$ & $\begin{array}{l}\text { Related to per } \\
\text { student cost in } \\
\text { public schools. Varies } \\
\text { somewhat between } \\
\text { municipalities }\end{array}$ \\
\hline $\begin{array}{l}\text { Regul. of } \\
\text { private }\end{array}$ & $\begin{array}{l}\text { National curr. Same } \\
\text { rules as for public } \\
\text { schools. }\end{array}$ & $\begin{array}{l}\text { National } \\
\text { curriculum. }\end{array}$ & $\begin{array}{l}\text { Same rules as for } \\
\text { public schools. Apply } \\
\text { national curriculum }\end{array}$ \\
\hline Testing & $\begin{array}{l}\text { National testing, } \\
\text { sporadically }\end{array}$ & National, annually & $\begin{array}{l}\text { National, systematic } \\
\text { testing annually in } \\
\text { certain grades }\end{array}$ \\
\hline Evaluation & $\begin{array}{l}\text { Bottom-up self- } \\
\text { evaluation. }\end{array}$ & Not systematiccally & $\begin{array}{l}\text { National } \\
\text { systematically in } \\
\text { sampled schools. } \\
\text { Bottom-up self- } \\
\text { evaluation. } \\
\end{array}$ \\
\hline Inspection & $\begin{array}{l}\text { National and } \\
\text { regional }\end{array}$ & Plan for national. & National and regional \\
\hline $\begin{array}{l}\text { Plans, } \\
\text { reports }\end{array}$ & $\begin{array}{l}\text { School plans, } \\
\text { bottom-up } \\
\text { reporting }\end{array}$ & \begin{tabular}{|l} 
None. \\
Plan for self- \\
evaluation.
\end{tabular} & $\begin{array}{l}\text { School plans, } \\
\text { bottom-up reporting }\end{array}$ \\
\hline
\end{tabular}




\section{Discussion and Conclusion}

First, a distinction needs to be made between (a) discourse (including symbolic policy-making), (b) policy-making, (c) decision-making, (d) implementation, and (e) outcomes. This paper has dealt mainly with (a) and (b) and to some extent with (d).

Globalization questions and challenges cultures and life styles and generates pressure on education to contribute to competitiveness and to focus on cognitive skills. The steering of education is changing in the direction towards the New Governance (features that largely appear in the world models). For influences in the European context, different concepts - such as Europeanization, Europeification, EU-ification... have been used (see, for instance, Featherstone, 2003). In this paper, focus has been mainly on the last mentioned concept. In Europe, the drive for competitiveness has resulted in certain changes in the educational systems, not least in regard to private schools and level of governance. The OMC mode of governance contains several elements of "endemic tentions". Radaelli (2003, pp. 27-29) argues that i) OMC seeks to de-couple issues, promote diversity and mute politics, (ii) competitiveness and "social Europe" are difficult to combine, and (iii) the balance between (inter-national) competition and cooperation (among member countires) is difficult to attain and maintain. For Gornitzka (2006, p. 39) the challenge is to keep a balance between institutionalisation, experimentation and disintegration. Radaelli $(2003$, p. 46) maintains that the OMC mode of governance contributes to socialisation of elites, and change in domestic opportunity structures. That is, the elites are trained to "think European", and those who participate in the EU-ification are likely to get new opportunities of power nationally through this participation. A change is taking place in educational thinking, at least among the elites.

In education, the OMC (especially the work with indicators for education policy at the European level) has resulted in a situation different from before the Lisbon agreement. Also, "the quantified aspects of the OMC process have been most deeply institutionalised and this is the most well-established part of the OMC in education, also compared to other sector OMCs" (Gornitzka, 2006, p. 35).

In all, some convergence in educational systems between the European countries has taken place in that (a) educational thinking is changing in the same direction, and (b) many countries (among them the three case countries) have adopted certain and similar aspects and elements of the world models. Such convergence tends to imply de-coupling of education from domestic characteristics. All three case countries have, at least during the decades following the second world war, had a unified education systems and monolithic policies. Such countries seem to have been more responsive than before to diversified demands for private schools, a feature that corresponds to some components of the world models. On the other hand, Greece has not responded to globalization and EU-ification to the same extent as the two other countries. Some variety of decentralization has been introduced in all countries during the past two decades, but less so in Greece.

Among the case countries, CR and Sweden have implemented NG components to a larger extent than the other countries, Greece to the smallest extent. This pattern 
seems to correspond to the countries' general way of dealing with globalization and Europeanization processes. However, in order for the NG to be fully implemented, effective response from stakeholders and local agents is required: school principals who take on the new decentralized tasks, parents exerting choice, people who establish private schools, and so on. With the restructuring of education since the end of the 1980s and beginning of the 1990s, such response has occurred mainly in CR and Sweden. More autonomy has been given to municipalities and schools, but at the same time (and perhaps therefore) extension and intensification of monitoring and supervision from the central and regional levels have been introduced. Decentralization has in some cases (e.g. Sweden) been combined with market mechanisms.

However, despite tendencies of convergence, a great deal of traditional educational patterns in Europe has survived. Or rather: The components of the NG have been less implemented in some countries, and when they have, the outcomes differ due to the interaction with the local and national contexts.

The NG in its wide sense has been fully implemented in Sweden, to a large extent in CR but less so in Greece. The certain outcomes of the NG reforms is change in administrative and decision-making structures and in installing new ones, but it seems to be less successful in terms of genuine local participation. Neither has any significant country-wise change (either improvement or deterioration) in student achievement been observed. Among the 25 European countries, only England has had some improvement in students level of knowledge (on international tests) since the beginning of the 1990s.

\section{References}

Abu-Duhou, I. (1999). School-based management. Paris: Unesco/IIEP.

Andeweg, R. B. (1996). Élite - Mass Linkages in Europe: Legitimacy Crisis or Party Crisis? Oxford Scholarship Online Monographs, 22, 143-164.

Apeldorn, van, B. (2000). The Political Economy of European Integration: Transnational Social Forces in the Making of Europe's Socio-Economic Order. In Stubbs R. and Underhill, G. R.. D. (eds). Political Economy and the Changing Global Order. $2^{\text {nd }}$ edition. Oxford: Oxford University Press.

Berger, P. L. (1999). The Desecularization of the World: A Global Overview. In P. L. Berger (ed.). The Desecularization of the World. Resurgent Religion and World Politics. Grand Rapids, Michigan: William B. Eerdmans Publishing.

Brown, T. (1999). Challenging globalization as discourse and phenomenon. International Journal of Lifelong Education, 18(1), 3-17.

Cox, R. W. (2000). Political Economy and World Order: Problems of Power and Knowledge at the Turn of the Millennium, in Stubbs, R. \& Underhill, G. R. D. (eds.), Political Economy and the Changing Global Order ( $2^{\text {nd }}$ edition). Oxford: Oxford University Press.

Dale, R. (2000). Globalization and education: Demonstrating a "common world educational culture" or locating a "globally structured educational agenda"? 
Educational Theory, 40(4), 427-428.

Daun, H. (2002). Globalization and National Education Systems. In Daun, H. (ed.), Educational Restructuring in the Context of Globalization and National Policy. New York: RoutledgeFalmer, pp. 1-31.

Daun, H. (2006). Globalization and the Governance of National Education Systems. In Daun, H. (ed.). School Decentralization in the Context of Globalizing Governance. International Comparison of Grassroots Responses. Dordrecht: Springer, pp. 5-26.

Daun, H. (2008). Islam, Christianity and Secularism in European Education. Journal of Policy Futures in Education, 6(6), 730-743.

Davie, G. (1999). Europe: The Exception that Proves the Rules? In Berger, P. L. (ed.), The Desecularization of the World: Resurgent Religion and World Politics. Grand Rapids, Ml: William B. Eerdman Publishing, pp. 65-84.

Elwell, F. W. (2006). Macrosociology: Four Modern Theorists. Paradigm Publishers. Retrieved on February 6, 2006 from <http//:www.faculty.rsu.edu/ felwell/ Theorists/Elwell/MajorWorks.html>.

European Commission (1997). Accomplishing Europe through Education and Training. Brussels: European Commission.

Eurybase (2005): Eurydice Database on Education Systems in Europe. Lund, Sweden: Centre for European Studies. Retrieved on May 15, 2006 from <http:// www.eurydice.org>.

Eurydice (2006).Private education in the European Union: Organisation, administration and the public authorities' role. Retrieved on August 20, 2008 from <http://www.eurydice.org/ressources/eurydice/ pdf/ 012EN/ 012EN.pdf>.

Eurydice (2007). School Autonomy in Europe. Policies and Measures. Brussels: European Commission.

Featherstone, K. (2003). Introduction: In the Name of 'Europe'. In K. Featherstone and C. Radaelli (eds.). The Politics of Europeanization. Oxford: Oxford Scholarship Online 2003. Retrieved February 22, 2010.

Foucault, M. (1991). Governmentality. In G. Burchell, C. Gordon \& P. Miller (eds.). The Foucault Effect. Studies in Governmentality. London: Harvester/Whatsheaf.

Gilbert, N. (2004). Transformation of the Welfare State: The Silent Surrender of the Public Responsibility. Oxford: Oxford University Press.

Gill, S. (2000). Knowledge, Politics, and Neo-Liberal Political Economy. In R. Stubbs and G. R. D. Underhill (eds.). Political Economy and the Changing Global Order. Oxford: Oxford University Press.

Gordon, C. (1991). Governmental rationality: an introduction. In G. Burchell, C. Gordon \& P. Miller (eds.). The Foucault Effect. Studies in Governmentality. London: Harvester/Whatsheaf.

Gornitzka, A. (2006). The Open Method of Coordination as pratice - A watershed in European education policy? Working Paper No 16. Oslo: Centre for European Studies, University of Oslo.

Greger, D. \& Walterová, E. (2007). In Pursuit of Educational Change: Transformation of Education in the Czech Republic. Orbis Scholae, 1(2), 11-44.

Halász, G. (2007). From Deconstruction to Systemic Reform: Educational 
Transformation in Hungary. Orbis Scholae, 1(2), 45-79.

Hamilton, L. (2003). Assessment as a Policy tool. Review of Research in Education, 27, 25-68.

Hannaway, J. \& Woodroffe, N. (2003). Policy Instruments in Education. Review of Research in Education, 27, 1-24.

Janowski, A. (2007). Educational Restructuring and Change: Post-Communist Educational Transformation in Poland. Orbis Scholae, 1(2), 80-109.

Johnson, N.(1987). The Welfare State in Transition. Brighton: Wheatsheaf Books.

Kooiman, J. (2000). Societal Governance: Levels, Modes, and Orders of SocialPolitical Interaction. In J. Pierre. (ed.). Debating Governance. Oxford: Oxford University Press.

Kozma, T. (1992). The Neo-Conservative Paradigm: Recent Changes in Eastern Europe. In Arnove, R. F., Altbach, P. G., \& Kelly, G. P. (eds.), Emergent Issues in Education. Comparative Perspectives. New York: SUNY Press.

Ladd, H. F. (2003). Introduction. In D. N. Plank \& G. Sykes (eds.). Choosing Choice. School Choice in International Perspective. New York and London: Teachers College Press.

Meyer, J. W., J. Boli, G. M. Thomas \& F. O. Ramirez (1997). World Society and NationState. American Journal of Sociology, 103(1), 144-181.

Nicaise, I.; Esping-Andersen, G. Pont, B. \& Tunstall, P. (2005): Equity in Education Thematic Review: Sweden Country Note. Paris: OECD. Retrieved on October 20, 2001 from <http://www.oecd.org $>$.

Norris, P. \& Inglehart, R. (2004): Sacred and Secular: Religion and Politics Worldwide. Cambridge: Cambridge University Press.

O'Connel, P.J. (1989). National Variation in the fortunes of labor: a pooled and crosssectional analysis of the impact of economic crisis in the advanced capitalist nations. In T. Janoski and A. M. Hicks (eds.). The Comparative Political Economy of the Welfare State. Oxford: Oxford University Press.

OECD (1995). Decision-making in 14 OECD Education Systems. Paris: OECD.

Offe, C. (1996). Modernity and the State. East, West. Cambridge, Mass.: The MIT Press.

Otero, M. S. \& McCoshan, A. (2004). Study on Access to Education and Training-Tender No EAC/38/04. Lot 1. Final Report for European Commission. Brussels: European Commission.

Radaelli, C. M. (2003). The Open Method of Coordination: A new governance architecture for the European Union. Stockholm: Swedish Institute for European Policy Studies.

Robertson, R. (1992). Globalization. Social Theory and Global Culture. London: Sage Publications.

Skolverket (2010). Children, pupils and staff- National level. Part 2, 2009. Stockholm: National Agency for Education.

Steenbergen, M.; Edwards, E. \& Netjes, C. (2005). Who's Cueing Whom? Assessing the Relationship between Electorate Opinion and Party Positions on the European Union. Paper presented at the annual meeting of the American Political Science Association, Marriott Wardman Park, Omni Shoreham, Washington Hilton, 
Washington, DC, 1 September 2005.

Sultana, R.G. (1995). A uniting Europe, a dividing education? Supranationalism, Euro-centrism and the curriculum. International Studies in Sociology of Education, 5(2), 115-144.

Tucker, C. M. (2003). The Lisbon Strategy and the Open Method of Coordination: A New Vision and the Revolutionary of Soft Governance in European Union. Paper presented at the 2003 Annual Meeting of the American Political Science Association, August 28 - August 31, 2003.

UNDP (2005). Human Development Report 2005. Oxford: Oxford University Press.

UNESCO (2005). World Education Report 1995. Paris: UNESCO.

Wallerstein, I. (2006). Modern History Sourcebook: Summary of Wallerstein on World System Theory. Retrieved on February 9, 2006 from <http://www.fordham.edu/ halsall/mod/wallerstein.html>..

Welsh, T. \& McGinn, N. F. (1999). Decentralization of education: why, when, what and how? Paris: IIEP/Unesco.

\section{Contact Information}

Prof. Holger Daun

Institute of International Education

Department of Education

Stockholm University

SE 10691 Stockholm

Sweden

holger.daun@interped.su.se 